Received: 3 April 2017

Accepted: 4 September 2017

Published online: 01 March 2018

\section{Application of Bld-1-Embedded Elastin-Like Polypeptides in Tumor Targeting}

\author{
Vijaya Sarangthem ${ }^{1}$, Eun A. Cho ${ }^{1}$, Aena Yi ${ }^{1}$, Sang Kyoon Kim² ${ }^{2}$ Byung-Heon Lee ${ }^{1} \&$ \\ Rang-Woon Park ${ }^{1}$
}

Expression of various molecules on the surface of cancer cells compared to normal cells creates a platform for the generation of various drug vehicles for targeted therapy. Multiple interactions between ligands and their receptors mediated by targeting peptide-modified polymer could enable simultaneous delivery of a drug selectively to target tumor cells, thus limiting side effects resulting from non-specific drug delivery. In this study, we synthesized a novel tumor targeting system by using two key elements: (1) Bld-1 peptide (SNRDARRC), a recently reported bladder tumor targeting peptide identified by using a phage-displayed peptide library, and (2) ELP, a thermally responsive polypeptide. $B_{5} V_{60}$ containing five Bld-1 peptides and non-targeted $\mathrm{ELP}_{77}$ with a thermal phase-transition over $37^{\circ} \mathrm{C}$ were analyzed to determine their bioactivities. Further studies confirmed the superior binding ability of $B_{5} V_{60}$ to bladder tumor cells and the cellular accumulation of $B_{5} V_{60}$ in cancer cells was dependent on the expression level of sialyl-Tn antigen (STn), a tumor-associated carbohydrate antigen. Additionally, $\mathrm{B}_{5} \mathrm{~V}_{60}$ displayed excellent localization in bladder tumor xenograft mice after intravenous injection and was strictly confined to sialyl-Tn antigen-overexpressing tumor tissue. Thus, our newly designed $\mathrm{B}_{5} \mathrm{~V}_{60}$ showed high potential as a novel carrier for STn-specific targeted cancer therapy or other therapeutic applications.

Delivery of drugs to tumor sites is necessary for effective cancer treatment. Therapeutic drug levels within a tumor are reduced due to the complex physiology and morphology of tumor tissue. Moreover, some chemo- and radiotherapeutic agents are toxic and cause undesirable side effects in healthy cells. Targeted-based delivery of drugs to tumors can improve cancer therapies by allowing anticancer agents to accumulate directly in tumor tissues, thereby enhancing overall therapeutic efficacy while minimizing systematic toxicity and side effects resulting from non-specific delivery of drugs ${ }^{1}$. Many active targeting strategies have been explored based on the unique features of tumors, including overexpressed receptors ${ }^{2,3}$, up-regulated enzymes ${ }^{4,5}$, reduced $\mathrm{pH}^{6,7}$, and hypoxia ${ }^{8,9}$ to enhance systematic delivery of drug carriers to tumors. Tumor cells have many molecular markers distinct from normal cells, such as high expression of growth factor receptors and variable expression of integrins, especially those that transmit growth signals ${ }^{10,11}$. The multivalent display of these targeting moieties on the exterior of nanoparticles or macromolecular carriers such as polymeric micelles, liposomes, proteins, and synthetic macromolecular polymers can result in increased avidity towards their corresponding receptors, which are overexpressed on tumor cells ${ }^{12-14}$. Moreover, studies have shown that theranostic agents based on nanovectors (liposomes, nanosomes, polymeric micelles) externally modified with targeting peptides are able to simultaneously carry a drug and contrast agent to target cells with an imaging probe co-incorporated in order to monitor therapy ${ }^{15}$.

Many peptides targeting specific organs, tumors, or proteins have been identified by the phage display screening method ${ }^{16-19}$. The three amino acid sequence RGD is a noble example of a targeting peptide that binds specifically to tumor vascular endothelial cells and also inhibits tumor angiogenesis ${ }^{20,21}$. Recently, Lee et al. identified a small peptide, SNRDARR, referred to as Bld-1, which shows high binding affinity to human bladder tumor tissue along with negligible binding to normal tissue ${ }^{22}$. Further study revealed that Bld-1 peptide is useful in detecting tumor cells in urine based on its weak binding to urinary cells of patients showing inflammation or to healthy individuals' cells ${ }^{23}$. Additionally, Bld-1 peptide shows homology with SIRDARR motif in human sialic acid-binding immunoglobulin-like lectins 6 and 9 (Siglec 6 and 9), which interact with Neu5Aco2-6GalNAco1(sialyl-Tn

${ }^{1}$ Department of Biochemistry and Cell Biology, Cell \& Matrix Research Institute, Kyungpook National University, School of Medicine, Daegu, 41944, Republic of Korea. ${ }^{2}$ Laboratory Animal Center, Daegu-Gyeonbuk Medical Innovation Foundation, Daegu, Republic of Korea. Vijaya Sarangthem and Eun A. Cho contributed equally to this work. Correspondence and requests for materials should be addressed to R.-W.P. (email: nwpark@knu.ac.kr) 
abbreviated as STn), a tumor-associated carbohydrate antigen that is overexpressed in various tumor cells $\mathrm{s}^{24-26}$. Overexpression of these antigens has been correlated with cancer progression, poor prognosis, and an immunosuppressive microenvironment, which suggests they are important therapeutic targets. So far therapeutic vaccination used for clinical trials and antibodies against this antigen have limited success due to low immunogenicity or specificity, thereby development of innovative targeted delivery system is needed for effective cancer treatment.

To create a targeted system with multiple targeting sites, we can exploit thermally responsive recombinant elastin-like polypeptide (ELP), as it can be readily tailored with desirable biological and mechanical properties. ELPs consist of Val-Pro-Gly-Xaa-Gly pentapeptide repeats (with "guest residue" Xaa is any amino acid except Pro) derived from a structural motif found in mammalian elastin ${ }^{27}$. Compared to other polymeric drug delivery systems, ELPs are biodegradable, biocompatible, and less toxic ${ }^{28,29}$. ELPs undergo an inverse temperature phase transition, in which they are soluble at temperatures below their transition temperature ( $\mathrm{Tt}$ ) but become insoluble and aggregate at temperatures above their $\mathrm{Tt}^{29}$. ELP polymers can be synthesized at the genetic level by recombinant DNA methods, which means that their sequences, compositions, and molecular weights can be precisely tuned. ELP polymers can be easily expressed and purified at high yield simply by exploiting the inverse temperature cycling (ITC) method $^{27}$. Studies have shown that genetically encoded synthesis of ELPs can be used to specify the location at which a biological drug, peptide, or protein is attached to an ELP sequence. Functionalization of ELP with targeting and internalization peptides has been found to improve accumulation and intracellular delivery of drugs at disease sites ${ }^{30}$. Fusion of ELP with a cell-penetrating peptide such as peptide derived from Drosophila Antennapaedia transcription factor (penetratin), HIV transactivation of transcription (TAT), and Kaposi fibroblast growth factor signal peptide (MTS) could increase intracellular delivery towards therapeutic targets, thereby enhancing drug efficacy ${ }^{30}$. Recently, it was demonstrated that penetratin-functionalized ELP-based delivery of kinase inhibitor peptide p 21 induces enhanced cancer cell death. ELP diblock copolymers designed with cell-penetrating peptide (CPP) domain at the hydrophilic end and a therapeutic domain at the hydrophobic end form a thermally responsive micelle-like structure and induce the multivalent display of CPP on the exterior to enhance cellular internalization ${ }^{31}$.

In a previous study, AP1-ELP polymers containing multiple IL-4 receptor-targeting peptides were shown to increase intracellular localization into tumor tissue ${ }^{32}$. Multivalent display of targeting peptide AP1 along the backbone of ELP polymer increased affinity towards its target, IL-4 receptor, by approximately 10,000-fold compared to free peptides. We performed further studies to create another multivalent targeted based ELP, containing bladder tumors targeting peptide Bld-1. Thus, to improve the binding avidity and specificity of Bld-1, $\mathrm{B}_{5} \mathrm{~V}_{60}$ was prepared by introducing multivalent Bld-1 into ELP polymer by genetic engineering, after which it's physical and bio-chemical properties were analyzed. Tumor targeting activities of $\mathrm{B}_{5} \mathrm{~V}_{60}$ were examined both in vitro and in vivo. Notably, the correlation of $\mathrm{STn}$ expression and $\mathrm{B}_{5} \mathrm{~V}_{60}$ binding with cancer cells was investigated. Competitive inhibition of cell binding induced by $\mathrm{B}_{5} \mathrm{~V}_{60}$ towards anti-STn antibody could be useful in STn-based targeting of cancer cells as a drug delivery system as well as in enhancing immune responses against immunotolerant tumor cells highly expressing STn.

\section{Results and Discussion}

Design and Preparation of Bld-1 ELP. As ELPs can be synthesized at the genetic level by the recombinant DNA method, their sequences, compositions, and molecular weights can be precisely controlled ${ }^{27}$. In addition, ELP polymer can accommodate any target-specific ligands or functional groups as well as support multivalent presentation without any physiological changes or biological activities. Accordingly, in this study, we modified the coding sequence of ELP (VGVPG; with guest residue Valine) by incorporating bladder tumor-specific peptide (Bld-1; SNRDARR). The monomer gene referred to as $\mathrm{B}_{1} \mathrm{~V}_{12}$ was designed with one Bld-1 sequence (SNRDARR) in its $\mathrm{N}$-terminal region, followed by 12 pentapeptide repeats of ELP. Using the recursive directional ligation method, targeted polymer of variable lengths $\left[B_{1} V_{12}\right]$ n were generated with periodic repetition of Bld- 1 throughout the polypeptide sequences. The pentapeptide ELP sequence VGVPG was used to construct the Bld-1 ELP library. Since Valine is a hydrophobic guest residue with a low Tt, it is expected that the increase in Tt due to incorporation of hydrophilic Bld-1 peptide is moderated and maintained within a relevant temperature range suitable for clinical application. The control ELP was constructed by ligation of $V_{21}$ with $\left[V_{3} G_{3} A_{3}\right]_{8}$ (Fig. 1A, Figure $\mathrm{S} 1$ ). Bld-1 ELP containing five Bld-1 peptides $\left(\mathrm{B}_{5} \mathrm{~V}_{60}\right)$ was used as a targeted polymer (Fig. 1B, Figure $\mathrm{S} 1$ ). $\mathrm{V}_{21}-\left(\mathrm{V}_{3} \mathrm{G}_{4} \mathrm{~A}\right)_{8}$ referred to as $\mathrm{ELP}_{77}$ was used as a non-targeted polymer for further in vitro and in vivo experiments. $\mathrm{B}_{5} \mathrm{~V}_{60}$ and control ELP $\mathrm{P}_{77}$ proteins were expressed by IPTG induction and purified using the inverse transition cycling (ITC) method. After four rounds of ITC, $\mathrm{B}_{5} \mathrm{~V}_{60}$ and $\mathrm{ELP}_{77}$ were analyzed by SDS-PAGE (Figure S2). The sizes of $\mathrm{B}_{5} \mathrm{~V}_{60}$ and $\mathrm{ELP}_{77}$ were approximately $\sim 30 \mathrm{kDa}$. Determination of accurate molecular weight by MALDI$\mathrm{TOF} / \mathrm{MS}$ confirmed the protein sizes of $\mathrm{ELP}_{77}(31341.8 \mathrm{Da})$ and $\mathrm{B}_{5} \mathrm{~V}_{60}(30649.2 \mathrm{Da})$ (Fig. 1C).

Thermal and Secondary Structure Characterization. Transition temperatures $(\mathrm{Tt})$ of $\mathrm{B}_{5} \mathrm{~V}_{60}$ and $\mathrm{ELP}_{77}$ proteins were monitored by measuring optical density at $350 \mathrm{~nm}$ as a function of temperature with $1{ }^{\circ} \mathrm{C} / \mathrm{min}$ increments. Transition temperature (Tt) of ELP protein was defined as the temperature at $50 \%$ of the maximum of ELP aggregation. The Tt of $\mathrm{B}_{5} \mathrm{~V}_{60}$ was in range of $37 \sim 40^{\circ} \mathrm{C}$ (Fig. 1D). Due to the presence of charge residues in Bld-1 peptide, the Tt of $\mathrm{B}_{5} \mathrm{~V}_{60}$ was elevated nearly $11^{\circ} \mathrm{C}$ compared to the control ELP without targeting peptide. The $\mathrm{Tt}$ of $\mathrm{B}_{5} \mathrm{~V}_{60}$ protein $\left(39.77^{\circ} \mathrm{C}\right)$ was just higher than physiological body temperature, whereas the same ELP without targeting peptide (negative control) had a Tt of $\sim 28^{\circ} \mathrm{C}$ (data not shown). Substitution of hydrophilic amino acids such as Glycine and Alanine at the fourth guest residue of the ELP pentapeptide repeat in the new non-targeted control $\mathrm{ELP}_{77}$ further increased Tt up to $38.67^{\circ} \mathrm{C}$ (Fig. 1D), approximately similar to that of targeted $\mathrm{B}_{5} \mathrm{~V}_{60}$. Measurement of turbidity profile at different concentration clearly reveal the dependency of $\mathrm{Tt}$ according to concentration (Figure S4). Despite lowering of Tt with increased concentration, their applicability was considered to be unaffected since relatively small change in Tt obtained by large increase in concentration ${ }^{33}$. Later 


\section{A $\quad \mathrm{ELP}_{77}=$ SGPG $(\mathrm{VGVPG})_{21}\left[(\mathrm{VGVPG})_{3}(\mathrm{GGVPG})_{3}(\mathrm{AGVPG})\right]_{8}$}

\section{B $\quad B_{5} V_{60}=$ SGPG [VGSNRDARRG (VGVPG) $\left.)_{12}\right]_{5}$}

C

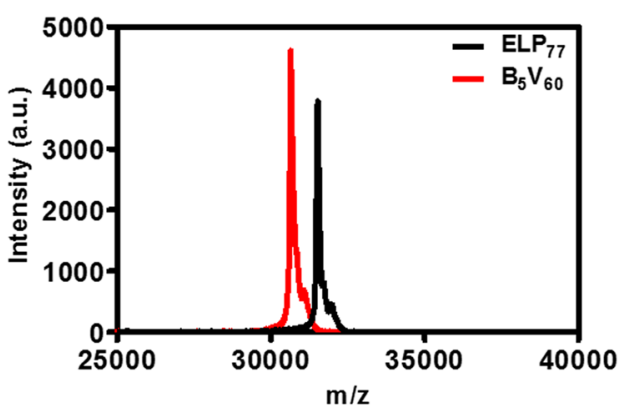

E

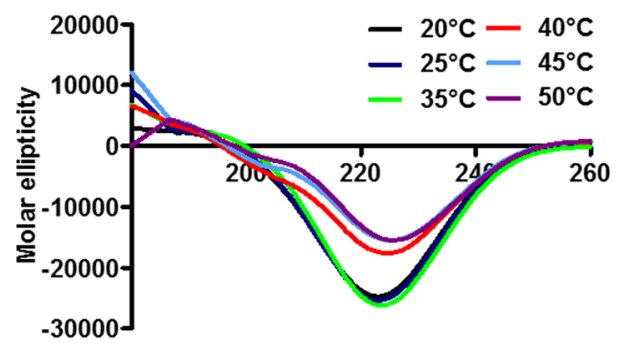

D

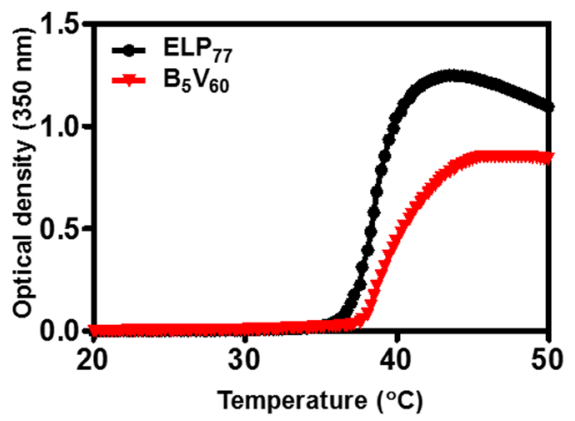

$\mathbf{F}$

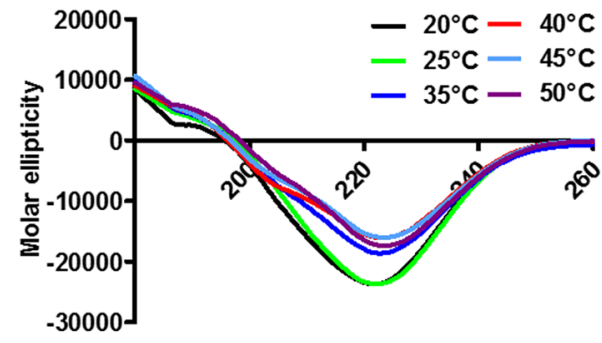

Figure 1. Chemical characterization of $\mathrm{B}_{5} \mathrm{~V}_{60}$ and $\mathrm{ELP}_{77}$. Corresponding amino acid sequences of $\operatorname{ELP}_{77}(\mathrm{~A})$ and $\mathrm{B}_{5} \mathrm{~V}_{60}$ (B). (C) MALDI-TOF MS spectra of $\mathrm{B}_{5} \mathrm{~V}_{60}$ and $\mathrm{ELP}_{77}$. (D) Turbidity profiles of $\mathrm{B}_{5} \mathrm{~V}_{60}$ and $\mathrm{ELP}_{77}$ proteins were monitored by measuring the absorbance at $350 \mathrm{~nm}$ at a rate of $1^{\circ} \mathrm{C} / \mathrm{min}$. Secondary structure of proteins $(\mathbf{E}) \mathrm{ELP}_{77}$ and $(\mathbf{F}) \mathrm{B}_{5} \mathrm{~V}_{60}$ was analyzed using Circular Dichroism at different temperatures and $25 \mu \mathrm{M}$ concentration.

determination of particle size at different temperatures $\left(24,37\right.$, and $\left.50^{\circ} \mathrm{C}\right)$ using DLS revealed the size increment with increased temperature in consistence with turbidity profile. But at physiological body temperature the size of $\mathrm{ELP}_{77}$ and $\mathrm{B}_{5} \mathrm{~V}_{60}$ were $415.5 \mathrm{~nm}$ and $413.4 \mathrm{~nm}$ respectively (Figure $\mathrm{S} 3$ ). As tumor vessels are predicted to be leakier due to irregular development of vasculature and uncontrolled angiogenesis with pores ranging in size from $200 \mathrm{~nm}$ to $2 \mu \mathrm{m}$, thus both polypeptides will be well penetrable in tumor tissue ${ }^{34}$. Further, circular dichroism (CD) spectra confirmed changes in secondary structure along with an increase in temperature in both $\operatorname{ELP}_{77}$ (Fig. 1E) and $\mathrm{B}_{5} \mathrm{~V}_{60}($ Fig. $1 \mathrm{~F})$ respectively. Both polypeptides appeared to structurally consist of a helix and $\mathrm{B}$-turn in a random coil conformation. Helix content increased at higher temperature in $\mathrm{B}_{5} \mathrm{~V}_{60}$ (Table S2), whereas helix formation decreased in $\mathrm{ELP}_{77}$ (Table S1). Both polymers displayed an increase in $ß$-turn content and slight decrease in random coil content at higher temperature. The increase in helix content in $B_{5} V_{60}$ was due to the presence of ligands Bld-1. However, incorporation of targeting ligands did not change the physical and chemical properties of ELP, clearly indicating its versatility in accommodating any functional peptide or protein.

In vitro Cell Binding Analysis. To analyze cell binding activity, Alexa 488-labeled $\mathrm{ELP}_{77}$ and $\mathrm{B}_{5} \mathrm{~V}_{60}$ proteins were incubated with 5637, HT-29, and HEK293 cells, and cellular binding was accessed using flow cytometry. Targeted $\mathrm{B}_{5} \mathrm{~V}_{60}$ polymer clearly revealed higher cellular binding activity compared to non-targeted ELP $\mathrm{P}_{77}$ polymer after $1 \mathrm{~h}$ of incubation at $4^{\circ} \mathrm{C}$ (Fig. $2 \mathrm{~A}$ ). $\mathrm{B}_{5} \mathrm{~V}_{60}$ polymer showed $17.44 \pm 2.08$-fold greater cell binding activity compared to $\mathrm{ELP}_{77}$ in 5637 cells. Further, $\mathrm{B}_{5} \mathrm{~V}_{60}$ polymer showed $1.29 \pm 1.08$-fold higher cell binding activity than free Bld-1 peptide (Fig. 2B). On the other hand, both polymers showed minimum binding activity in HT-29 (Fig. 2C,D) and HEK-293 cells (Fig. 2E,F). Thus, multivalent presentation of Bld-1 peptide along the ELP backbone increased cellular accumulation of tumor cells. In addition, $\mathrm{B}_{5} \mathrm{~V}_{60}$ polymer showed $5.18 \pm 1.28$-fold greater cell attachment in 5637 cells compared to HT-26 cells. These results clearly suggest that $\mathrm{B}_{5} \mathrm{~V}_{60}$ is highly specific to bladder tumors. Consistent with the flow cytometry data, confocal microscopy of adherent cells demonstrated that $\mathrm{B}_{5} \mathrm{~V}_{60}$ polymer was localized more efficiently onto the surface of 5637 cells (Fig. $3 \mathrm{~A}$ ) at $4{ }^{\circ} \mathrm{C}$. In contrast, minimum localization was observed in HT-29 (Figure S5A) and HEK293 (Figure S6A) cells upon incubation with respective polymers. Further, $\mathrm{B}_{5} \mathrm{~V}_{60}$ polymer displayed improved cellular uptake towards 5637 cells (Fig. 3B) compared to HT-29 (Figure S5B) and HEK-293 (Figure S6B) cells upon incubation at $37^{\circ} \mathrm{C}$ for 30 min. Neither $\mathrm{ELP}_{77}$ nor $\mathrm{B}_{5} \mathrm{~V}_{60}$ showed significant cellular uptake by HT-29 and HEK-293 cells. These results clearly indicate that multiple Bld-1 peptide incorporation by the ELP polymer backbone resulted in greater tumor specific accumulation and uptake compared to the non-targeted ELP control. Together, it was confirmed that $B_{5} \mathrm{~V}_{60}$ showed no accumulation in normal cells, which is crucial for drug delivery systems. 
A

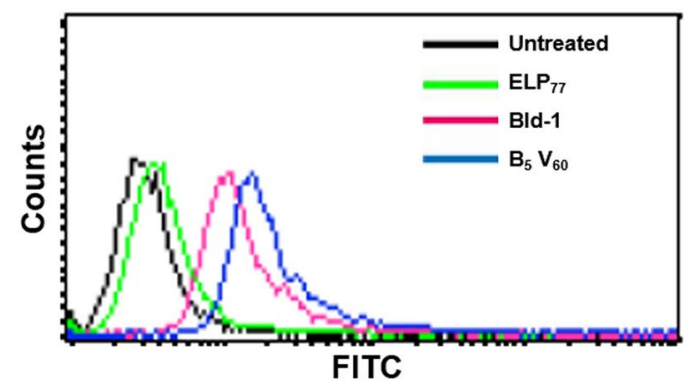

C

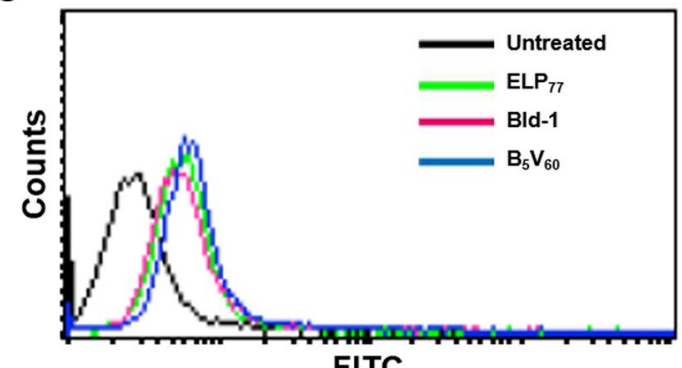

E

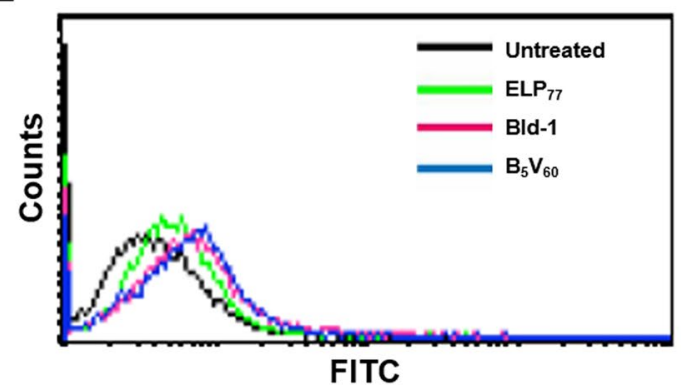

B

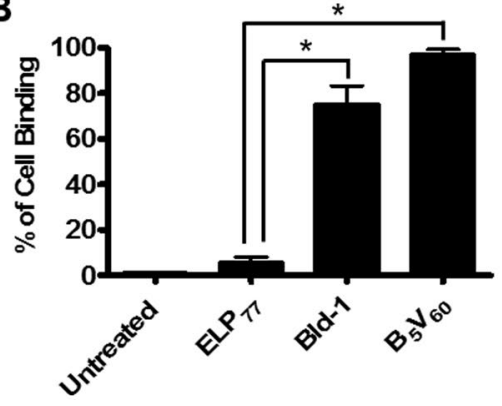

D

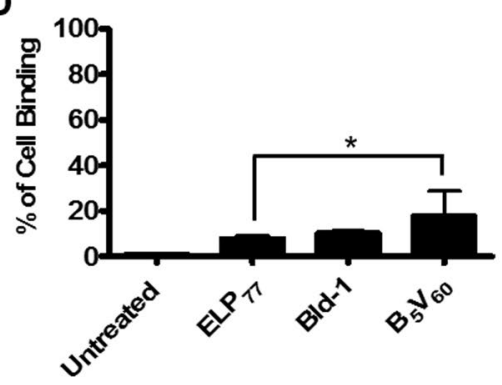

$F$

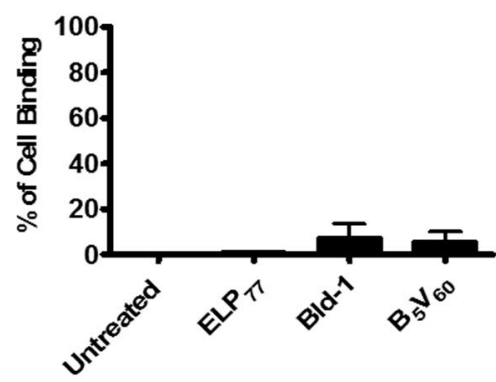

Figure 2. Determination of binding activity in vitro. 5637 (A,B), HT-29 (C,D), and HEK-293 (E,F) cells were incubated with $10 \mu \mathrm{M} \mathrm{B}_{5} \mathrm{~V}_{60}$ and $\mathrm{ELP}_{77}$ for $1 \mathrm{~h}$ at $4^{\circ} \mathrm{C}$. Percentage of cell binding was determined using flow cytometry. Histograms (on right) are representative of five independent experiments $(\mathrm{n}=5)$. $* \mathrm{P}<0.05$ (Student's t-test) when $\mathrm{B}_{5} \mathrm{~V}_{60}$ and Bld-1 treated cells were compared to $\mathrm{ELP}_{77}$.

STn Expression Determination and Competition Assay. In previous study it was specified through homology search that Bld-1 peptide shows similarity with SIRDARR motif found in human sialic acid binding immunoglobulin-like lectin 6 and 9 (Siglec 6 and 9) which interact with Neu5Aca2-6GalNAca1 (sialosyl-Tn, STn) a tumor-associated carbohydrate antigen, overexpressed in various tumor cells ${ }^{24-26}$. Thus, we investigated the level of STn expression in 5637 and HT-29 cells by flow cytometry. Higher expression (up to $45 \pm 5 \%$ ) of STn was observed in 5637 cells (Fig. 4B) in contrast to lower expression (around 15 $\pm 3 \%$ ) in HT-29 cells (Fig. 4A). Increased binding of $\mathrm{B}_{5} \mathrm{~V}_{60}$ to 5637 cells as well as lower binding to HT-29 cells may be correlated with STn expression. To confirm STn-dependent binding of $\mathrm{B}_{5} \mathrm{~V}_{60}$, competition assay was performed where 5637 cells were pre-incubated with different concentrations of anti-STn antibody ( 5 and $10 \mu \mathrm{g})$, and binding of respective polypeptide was measured by flow cytometry. Binding of $\mathrm{B}_{5} \mathrm{~V}_{60}$ was remarkably reduced in a concentration-dependent manner upon pre-incubation with anti-STn antibody (Fig. 4D,E). At a higher antibody concentration of $10 \mu \mathrm{g}$, binding of $\mathrm{B}_{5} \mathrm{~V}_{60}$ was reduced by two-fold in comparison with the isotype control. Minimum or no change in binding was observed when cells were incubated with $\mathrm{ELP}_{77}$ (Fig. 4C,E). This result demonstrates that accumulation of $\mathrm{B}_{5} \mathrm{~V}_{60}$ on cells is highly dependent on the level of STn expression by cancer cells.

Next, we performed co-localization assay to confirm specific $B_{5} V_{60}$ binding to $S T n$, which is highly expressed in some tumor cells. Confocal microscopic images clearly revealed a greater accumulation of $\mathrm{B}_{5} \mathrm{~V}_{60}$ and anti-STn antibody on the surface of 5637 cells (Fig. 5B). Minimum accumulation was observed when cells were incubated with $\mathrm{ELP}_{77}$ (Fig. 5A). Merged image showed improved co-localization, which further proves that both proteins shared the same binding target. On the other hand, $\mathrm{B}_{5} \mathrm{~V}_{60}$ and anti-STn antibody displayed lower binding in HT-29 cells (Figure S7). These results demonstrate that binding of $\mathrm{B}_{5} \mathrm{~V}_{60}$ to tumor cells is dependent on STn expression by cancer cells.

In vivo Biodistribution of $\mathrm{B}_{5} \mathrm{~V}_{60}$ in Tumor Bearing Mice. In relation to the significant tumor-specific in vitro targeting activity of $\mathrm{B}_{5} \mathrm{~V}_{60}$, in vivo selective homing towards tumor tissue was determined using a live optical imaging system. Prior to the biodistribution study, the stabilities of FPR-675-labeled polypeptides were examined by incubation in fresh plasma for different time intervals at $37^{\circ} \mathrm{C}$. Measurement of fluorescent intensities 
A

DAPI

Alexa-488

WGA-Alexa-594

DIC

Merge

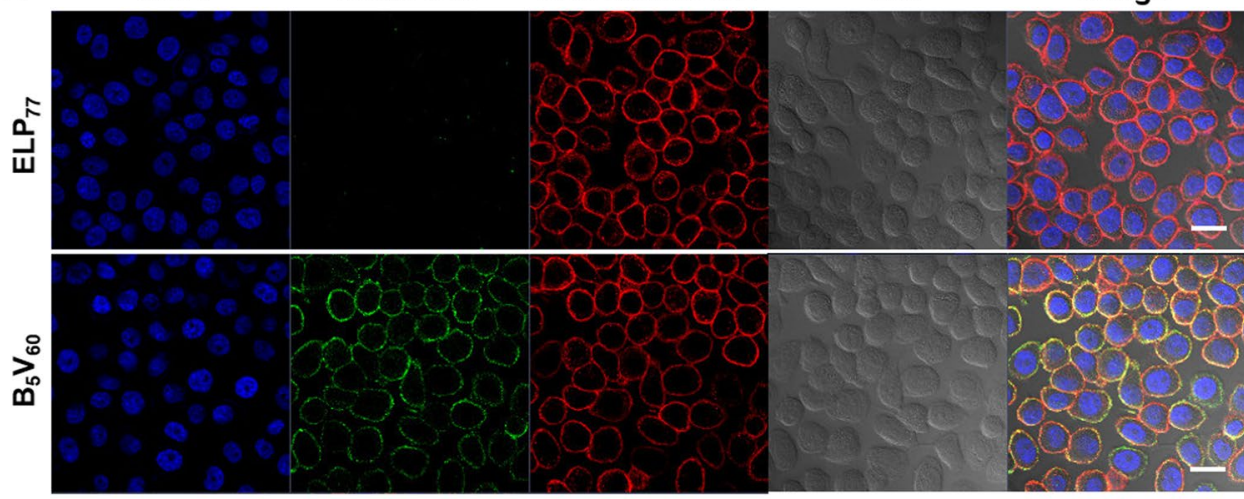

B

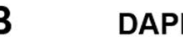

DAPI

Alexa-488

WGA-Alexa-594

DIC

Merge

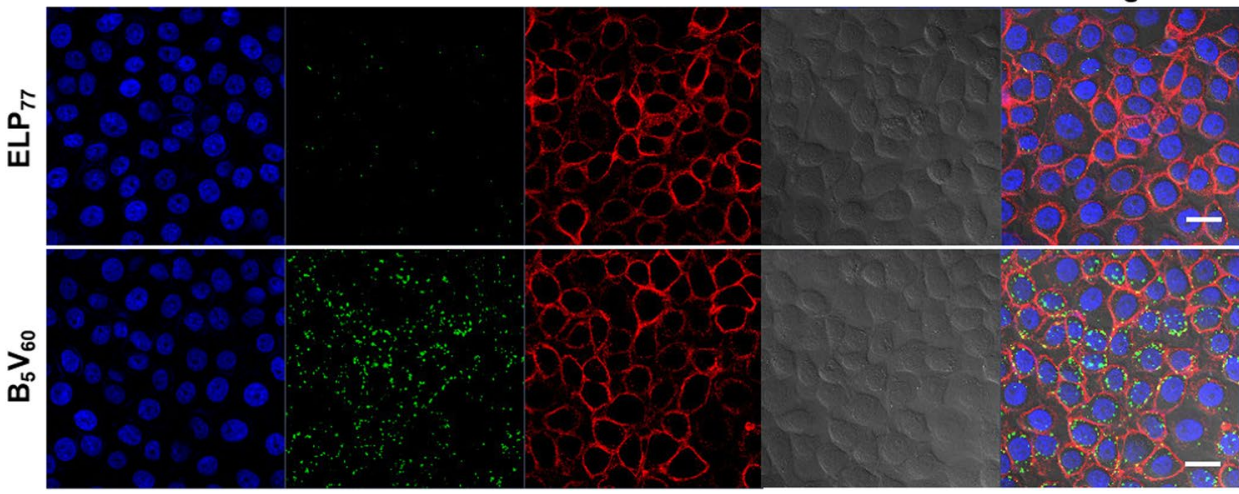

Figure 3. Studies of cellular localization in vitro. Confocal images of 5637 cells treated with $10 \mu \mathrm{M} \mathrm{B}_{5} \mathrm{~V}_{60}$ or $\mathrm{ELP}_{77}$ at $4{ }^{\circ} \mathrm{C}(\mathbf{A})$ and $37^{\circ} \mathrm{C}(\mathbf{B})$. Cell membrane and nuclei were stained with WGA Alexa 594 and DAPI respectively. Representative confocal images of three experiments (Scale bar $20 \mu \mathrm{m}$ ).

with excitation and emission wavelengths of $675 \mathrm{~nm}$ and $698 \mathrm{~nm}$, respectively, after ITC confirmed that nearly $18-20 \%$ of dye was released over $24 \mathrm{~h}$, confirming the dye was firmly conjugated to its respective polypeptides (Figure S8A). Further measurement of the fluorescent intensities of serially diluted labeled $\mathrm{B}_{5} \mathrm{~V}_{60}$ and $\mathrm{E}_{147}$ polypeptides showed a dose-dependent decrease in intensity with no significant difference (Figure S8B). Thus, after confirming labeling efficiency, athymic mice bearing 5637 bladder tumors were injected intravenously with respective polymers labeled with FNR-675. Near infrared fluorescence (NIRF) images taken at different time intervals showed that $\mathrm{B}_{5} \mathrm{~V}_{60}$ polymers were rapidly distributed within $10 \mathrm{~min}$ and accumulated time-dependently in tumor tissue (Fig. 6A). At $2 \mathrm{~h}$ post-injection, high fluorescence intensity in target tumors was observed in mice injected with $\mathrm{B}_{5} \mathrm{~V}_{60}$ polymer and persisted longer than $24 \mathrm{~h}$ (Figure $\mathrm{S} 9$ ). In contrast, the $\mathrm{ELP}_{77}$ control showed low accumulation towards tumor tissue compared to high accumulation in other organs. Thus, despite having the same chemical characteristics, $\mathrm{B}_{5} \mathrm{~V}_{60}$ showed superior tumor accumulation than the ELP $\mathrm{P}_{77}$ control due to the presence of multiples copies of targeting ligands. Ex vivo fluorescence images of excised tumors and organs collected at $24 \mathrm{~h}$ post-injection showed a 2.3 -fold increase in fluorescence intensity in target tumors of $\mathrm{B}_{5} \mathrm{~V}_{60}$-injected mice compared to $\mathrm{ELP}_{77}$ injection (Fig. 6B). Higher accumulation in kidneys was observed in both $\mathrm{ELP}_{77}$ and $\mathrm{B}_{5} \mathrm{~V}_{60}$-injected mice due to rapid metabolism. Since protein molecular weight has a strong effect on biodistribution in vivo, higher kidney accumulation may be attributed to the lower molecular weights of both polypeptides $^{35}$. However, fluorescence intensity in the liver was stronger in $\mathrm{ELP}_{77}$-injected mice compared to $\mathrm{B}_{5} \mathrm{~V}_{60}$ (Fig. 6C). Together, immunohistological examination of tumor tissue showed that $\mathrm{B}_{5} \mathrm{~V}_{60}$ was highly confined to STn-expressing tumor tissue, consistent with in vivo and ex vivo imaging results (Fig. 7). Collectively, these results further confirm the potential of $\mathrm{B}_{5} \mathrm{~V}_{60}$ as a candidate macromolecular drug carrier for cancer therapy.

\section{Conclusion}

In this study, we demonstrated the potential of genetically encoded synthesis of ELP polypeptide in which multiple tumors targeting peptides are randomly incorporated into the polypeptide backbone without the need for covalent attachment chemistry. Multivalent presentation of bladder tumor-targeting peptide onto the ELP backbone can increase cellular uptake compared to monovalent Bld-1 peptide and the non-targeted ELP control. Consistent with previous findings demonstrating the multivalent presentation of ELP with IL-4 receptor-targeting peptide has efficient targeting ability both in vitro and in vivo, this study further confirms our strategy of seamlessly incorporating functional peptides. An in vivo study revealed that $\mathrm{B}_{5} \mathrm{~V}_{60}$ polymer accumulated in tumor tissue and was retained for over $24 \mathrm{~h}$. Accumulation of $\mathrm{B}_{5} \mathrm{~V}_{60}$ on tumor cells was highly correlated with the expression level of STn (sialyl-Tn). Since high expression of STn on cell surfaces is related with advanced-stage tumor 
A

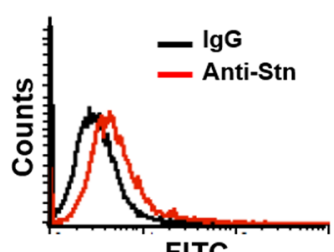

FITC

C

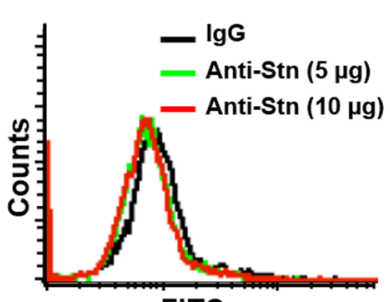

FITC

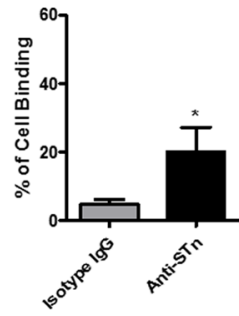

D
B
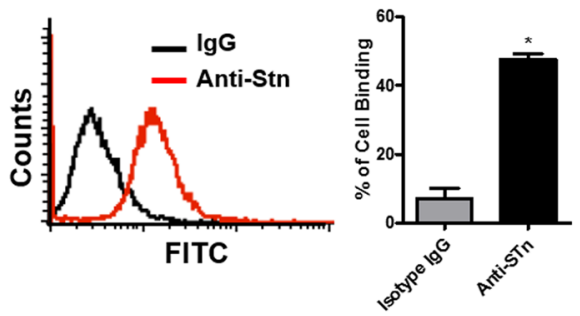

E

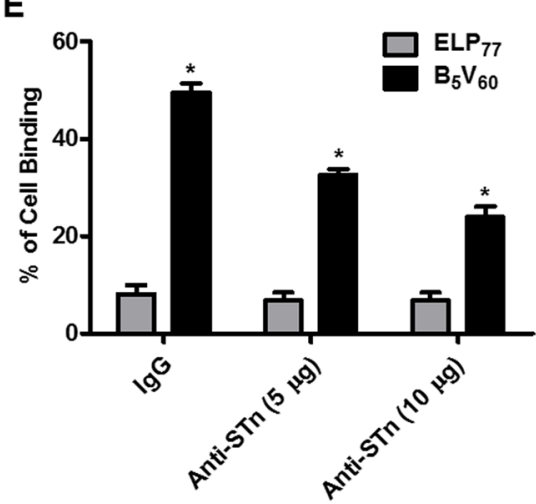

Figure 4. Estimation of STn expression and competition assay. STn expression levels of HT-29 cells (A) and 5637 cells (B) were measured using flow cytometry after incubation with anti-STn-Alexa 488 antibody for $1 \mathrm{~h}$ at room temperature. 5637 cells $\left(1 \times 10^{6}\right)$ were pre-incubated with different concentrations of anti-STn antibody $(5$ and $10 \mu \mathrm{g} / \mathrm{ml}$ ) for $1 \mathrm{~h}$ at room temperature. The cells were further incubated with $10 \mu \mathrm{M} \mathrm{ELP}_{77}(\mathbf{C})$ and $\mathrm{B}_{5} \mathrm{~V}_{60}(\mathbf{D})$ at $4^{\circ} \mathrm{C}$. Histograms are representative of five independent experiments $(n=5)$. Inhibition of binding activity were analyzed through flow cytometry. (E) Percentage of cell binding by ELP $\mathrm{F}_{77}$ and $\mathrm{B}_{5} \mathrm{~V}_{60}$ after pre-incubation with anti-STn antibody. $* \mathrm{P}<0.05$ (Student's t-test) for $\mathrm{ELP}_{77}$ versus $\mathrm{B}_{5} \mathrm{~V}_{60}$.

and malignancy, our newly design $\mathrm{B}_{5} \mathrm{~V}_{60}$ polymer offers an approach for application of novel therapeutics such as selective drug-delivery or STn-based immunotherapy. Subsequently, this strategy can be further optimized to study the association of tumor-associated carbohydrate antigens with immune cells.

\section{Methods}

ELP Nomenclature. ELPs are designated as ELP $\left[\mathrm{X}_{\mathrm{a}} \mathrm{Y}_{\mathrm{b}} \mathrm{Z}_{\mathrm{c}}\right] \mathrm{n}$ where $\mathrm{X}, \mathrm{Y}$, and $\mathrm{Z}$ specify the guest residue, a, $b$, and $c$ are the numbers of corresponding guest residue repeats, and ' $n$ ' denotes the number of monomer gene repeats for RDL. For example, $\mathrm{V}_{3} \mathrm{G}_{4} \mathrm{~A}$ consists of seven pentapeptide XGVPG repeats with Valine, Glycine, and Alanine as guest residues $(\mathrm{X})$. In this experiment, $\mathrm{B}_{5} \mathrm{~V}_{60}$ consisted of $\mathrm{B}$ as Bld-1 peptide and $\mathrm{V}$ as VGVPG with 60 repeats. $\left[\mathrm{V}_{21}\left(\mathrm{~V}_{3} \mathrm{G}_{3} \mathrm{~A}\right)_{8}\right]$ refers to an $\mathrm{ELP}_{77}$ consisting of 77 pentapeptide repeats with Valine, Glycine, and Alanine as guest residues (VGVPG, GGVPG, AGVPG) used as a control.

ELP Gene Oligomerization and Expression. Synthetic oligonucleotides encoding monomer genes of $\mathrm{V}_{7},\left(\mathrm{~V}_{3} \mathrm{G}_{3} \mathrm{~A}\right)$ and VGSNRDARRG- $\mathrm{V}_{5}$ containing BamH I, PflM I, Bgl I, and HinD III enzyme sites were obtained from Macrogen Inc. Seoul, Korea. Corresponding oligonucleotides were annealed and ligated into BamH I and Hin D III double-digested pRSET B vector. The pRSET B containing $\mathrm{V}_{7}$ was linearized with PflM I, enzymatically dephosphorylated with Calf intestinal alkaline phosphatase (CIP), and ligated with VGSNRDARRG- $V_{5}$ double-digested with PflM I and $B g l$ I. The resulting $\left(V G S N R D A R R G-\mathrm{V}_{5}\right)_{2}$ designated as $\mathrm{B}_{1} \mathrm{~V}_{12}$ was used as a monomer gene to synthesize Bld-1 ELPs with various lengths by RDL. On the other hand, $V_{7}$ and $V_{3} G_{4} A$ were used as monomer genes to synthesize ELPs with various length by RDL. After gene oligomerization by RDL, Bld1-ELP with various lengths $(\mathrm{n}=2,4,5$, and 6$)$ and different transition temperatures was obtained, and $\mathrm{B}_{5} \mathrm{~V}_{60}$ containing five Bld-1 peptides was used for further experimentation. In order to construct $\mathrm{ELP}_{77}$ control $\left[\mathrm{V}_{21}\right.$ $\left(\mathrm{V}_{3} \mathrm{G}_{4} \mathrm{~A}\right)_{8}$, pRSET B containing $\mathrm{V}_{21}$ was doubled-digested with $P f l \mathrm{M} \mathrm{I}$ and $B g l \mathrm{I}$ and ligated into $\left(\mathrm{V}_{3} \mathrm{G}_{3} \mathrm{~A}\right)_{8}$ containing vector linearized with PflM I. Positive colony were confirmed through restriction digestion with BamH I and HinD III, followed by gene sequencing (Macrogen Inc. Seoul, Korea).

ELP Gene Expression. For protein expression, expression vector pET $25 \mathrm{~b}+$ vector was modified by liga-

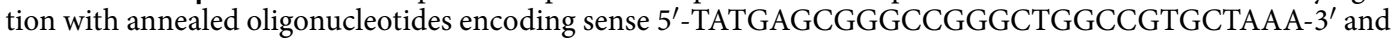
anti-sense $5^{\prime}$-AGCTTTTAGCACGGCCAGCCCGGCCCGCTCA- $3^{\prime}$ containing Nde I, Sfi I, and HinD III restriction enzyme sites. After confirmation through DNA sequencing, modified pET25b+ vector was digested with $S f l \mathrm{I}$, and $\mathrm{ELP}_{77}$ or $\mathrm{B}_{5} \mathrm{~V}_{60}$ gene was ligated and transformed into DH5 $\alpha$ competent $E$. coli. Positive colonies were 
A
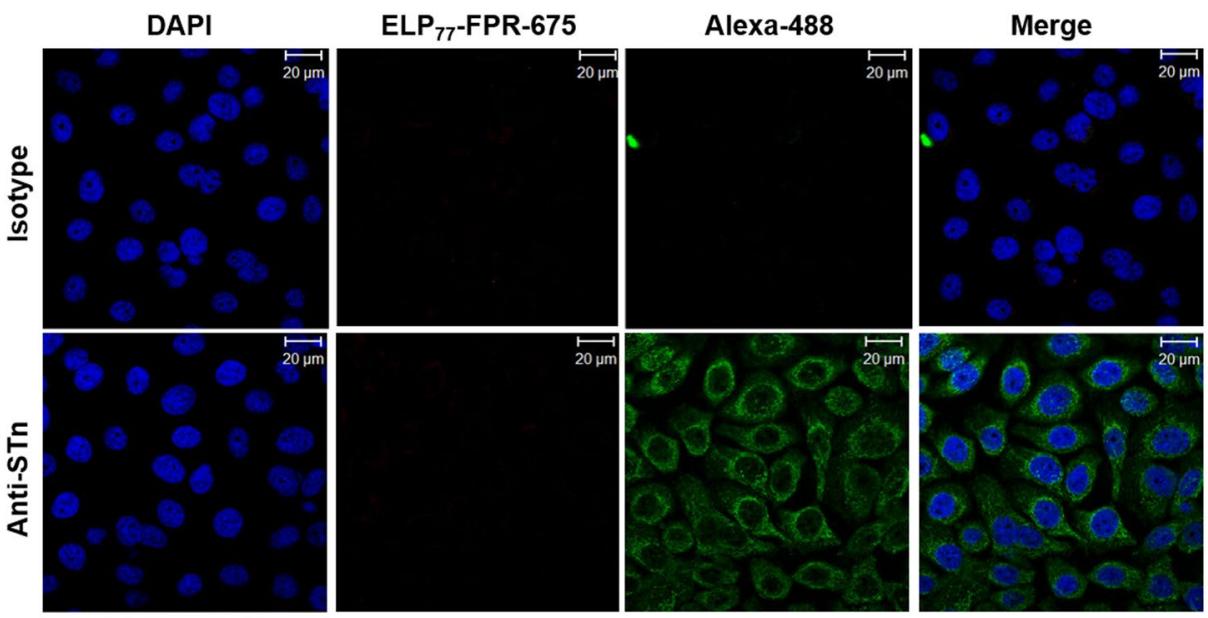

B
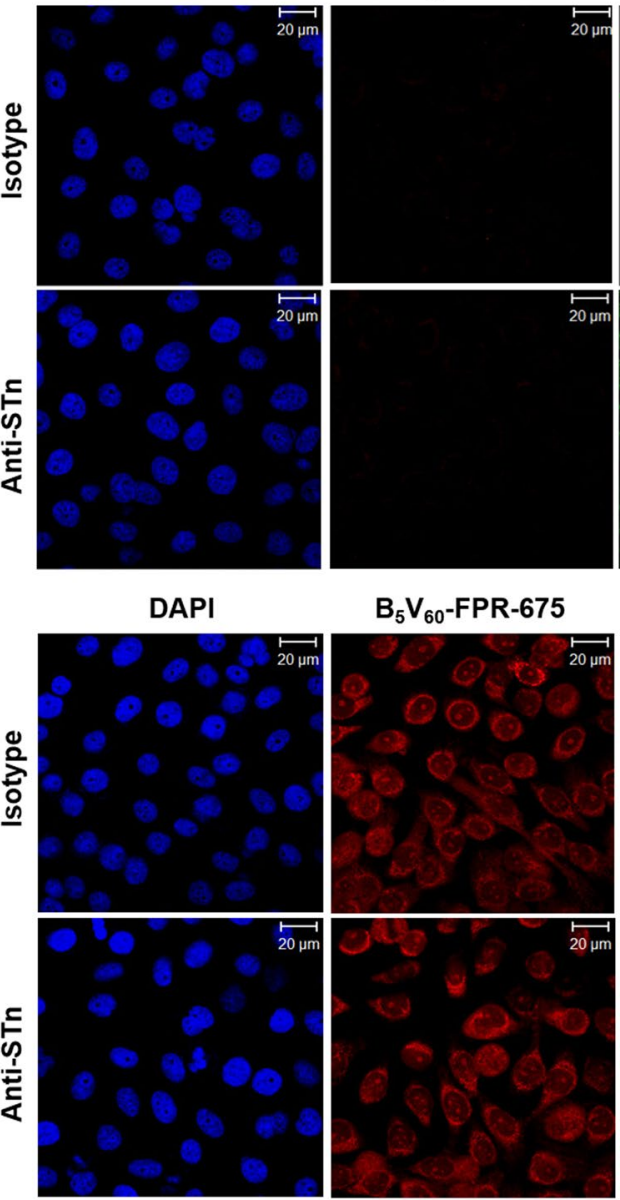

$B_{5} V_{60}$-FPR-675
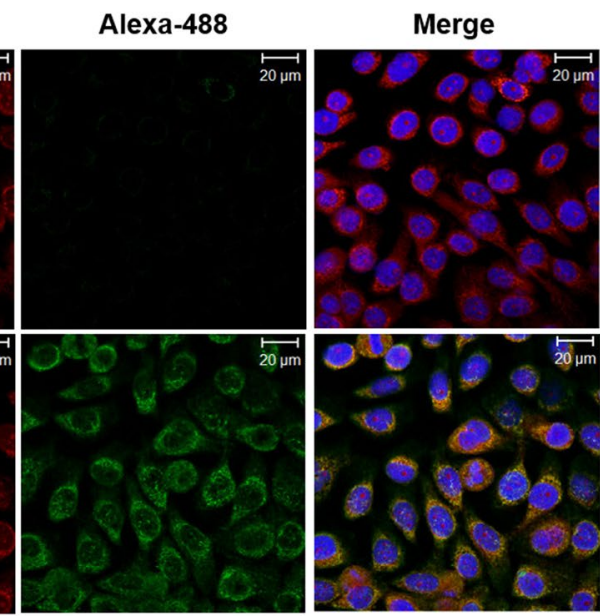

Figure 5. Co-localization Assay. 5637 cells $\left(1 \times 10^{6}\right)$ were pre-incubated with anti-STn-Alexa $488(1: 100)$ and further incubated with $10 \mu \mathrm{M} \mathrm{ELP}_{77}(\mathbf{A})$ and $\mathrm{B}_{5} \mathrm{~V}_{60}(\mathbf{B})$ at $4^{\circ} \mathrm{C}$. Co-localization of protein and antibody was analyzed using confocal microscopy. Representative confocal images of three experiments (Scale bar $20 \mu \mathrm{m}$ ).

confirmed through restriction digestion with Nde I and HinD III, followed by gene sequencing (Macrogen Inc. Seoul, Korea).

ELP Protein Purification. For protein expression, BL21 (DE3) chemically competent E. coli cells were further transformed with modified pET $25 \mathrm{~b}+$ vector containing $\mathrm{ELP}_{77}$ and $\mathrm{B}_{5} \mathrm{~V}_{60}$ gene. Starter cultures were prepared after inoculation of expression strain in $15 \mathrm{ml}$ of Circle Grow media supplemented with $100 \mu \mathrm{g} / \mathrm{ml} \mathrm{of}$ ampicillin overnight at $37^{\circ} \mathrm{C}$. The starter cultures were further incubated with $800 \mathrm{ml}$ of fresh Circle Grow media containing ampicillin at $37^{\circ} \mathrm{C}$ until it reached 0.8-1.0 at O.D 600. Protein expression was induced by addition of $1 \mathrm{mM}$ solution of IPTG. Cells were then harvested after $4 \mathrm{~h}$ by centrifugation at $4000 \mathrm{rpm}$ for $20 \mathrm{~min}$ at $4^{\circ} \mathrm{C}$ and suspended in $10 \mathrm{ml}$ PBS. Cells were lysed by sonication at $4^{\circ} \mathrm{C}$ and purified using inverse transition cycling (ITC). Four rounds of ITC were conducted to remove all contaminants. ELP expression and purity were analyzed by SDS-PAGE, followed by Copper chlorite staining. Protein concentration was measured by Cary UV-Vis spectroscopy using an extinction coefficient of $5690 \mathrm{M}^{-1} \mathrm{~cm}^{-1}$ for both $\mathrm{ELP}_{77}$ and $\mathrm{B}_{5} \mathrm{~V}_{60}$.

MALDI TOF/MS Analysis. Accurate molecular weights of $\mathrm{ELP}_{77}$ and $\mathrm{B}_{5} \mathrm{~V}_{60}$ were determined using an UltrafleXtreme (Bruker). For the measurement, proteins were dissolved with $0.1 \%$ trifluoroacetic acid and mixed with an equal volume of matrix solution (1:1). Resultant mixture $(1 \mu \mathrm{l})$ was then applied to a standard steel target for drying at room temperature. The spectra were obtained after calibration with standards.

Thermal Characterization. Transition temperature $(\mathrm{Tt})$ of $\mathrm{ELP}_{77}$ and $\mathrm{B}_{5} \mathrm{~V}_{60}$ were determined by monitoring the turbidity profiles of protein solutions at a wavelength of $350 \mathrm{~nm}$ as a function of temperature using a UV-visible spectrophotometer (Agilent Technologies, CA, USA). The absorbance was monitored from $20^{\circ} \mathrm{C}$ to $50{ }^{\circ} \mathrm{C}$ with $1{ }^{\circ} \mathrm{C} / \mathrm{min}$ increments. The first derivative of the turbidity profile with respect to temperature was numerically calculated, and the $\mathrm{Tt}$ was defined as the solution temperature at $50 \%$ of the maximum turbidity gradient. The Tt of $\mathrm{ELP}_{77}$ and $\mathrm{B}_{5} \mathrm{~V}_{60}$ protein were monitored at $10 \mu \mathrm{M}$ concentration. 
A

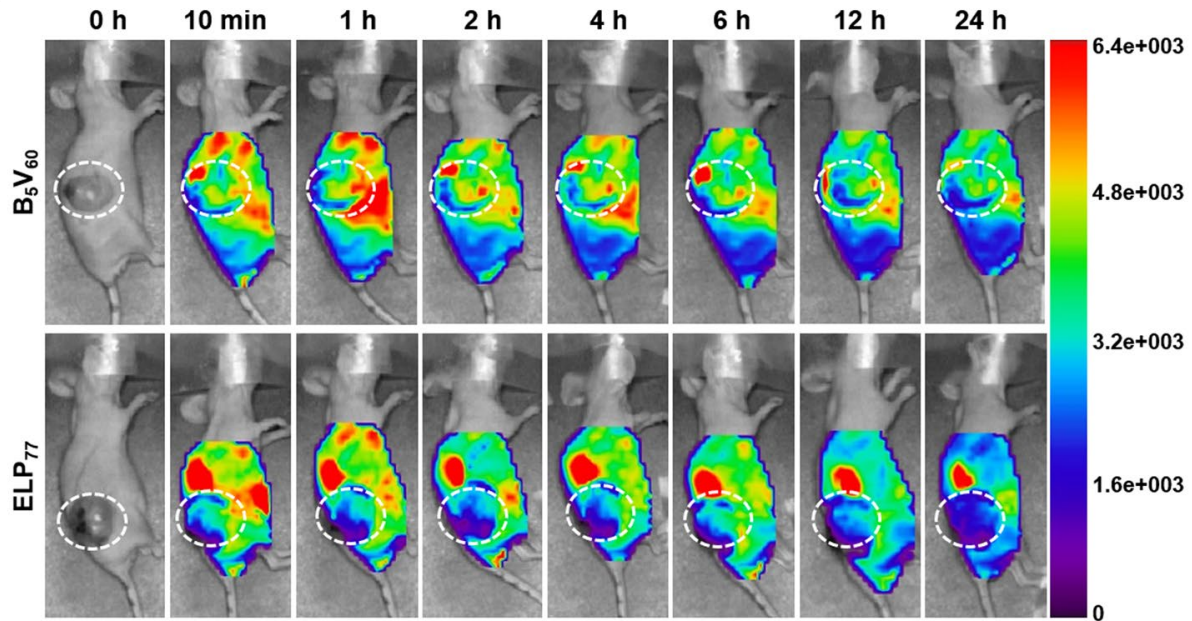

B

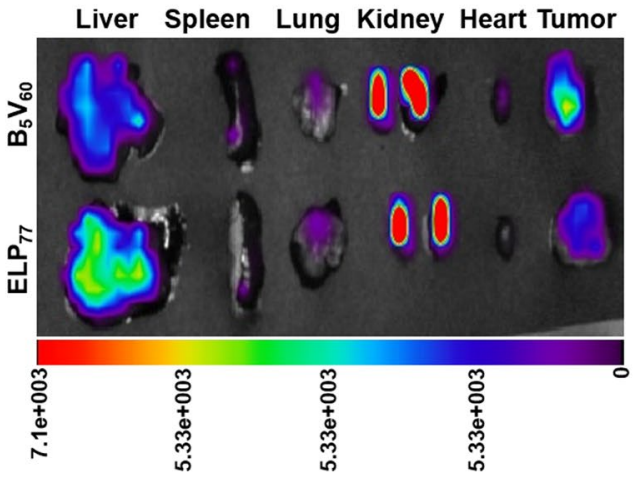

C

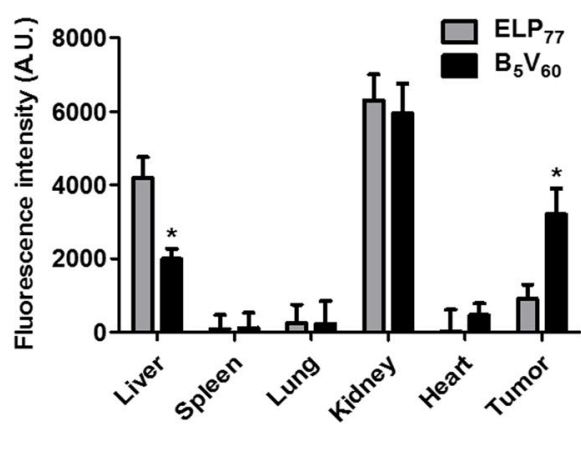

Figure 6. In vivo imaging and biodistribution of $\mathrm{B}_{5} \mathrm{~V}_{60}$. (A) $\mathrm{ELP}_{77}$ and $\mathrm{B}_{5} \mathrm{~V}_{60}$ labeled with FNR 675 were intravenously injected into 5637 tumor xenograft nude mice. Fluorescence images were taken at different time intervals such as $0.1,1.2,4,6,12$, and $24 \mathrm{~h}$ to study biodistribution in vivo $(\mathrm{n}=10)$. Scale bar indicates normalized fluorescence intensity. (B) Fluorescence images of excised organs and tumor at $24 \mathrm{~h}$ after intravenous injection. Representative images of subsequent 10 experiments. Scale bar indicates normalized fluorescence intensity. (C) Analysis of fluorescence intensities of excised organs, including tumor tissue $(n=8)$. $* \mathrm{P}<0.05$ (Student's t-test) for $\mathrm{ELP}_{77}$ versus $\mathrm{B}_{5} \mathrm{~V}_{60}$.
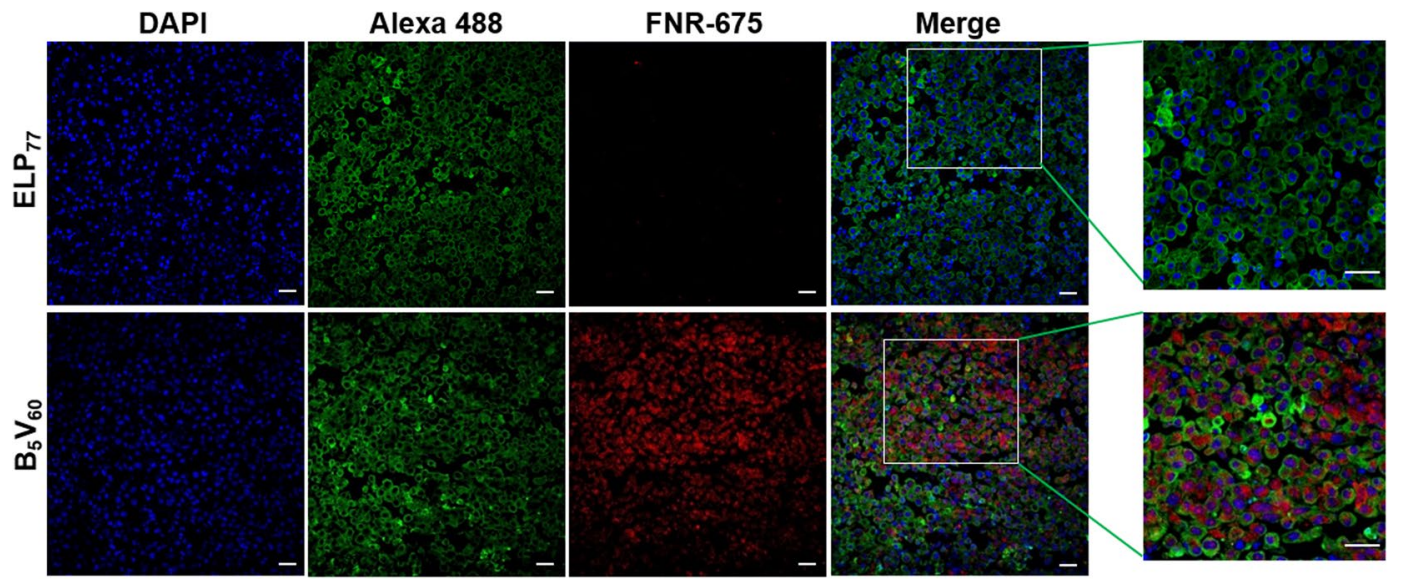

Figure 7. Ex vivo staining: Cryo-section of tumor tissue stained with anti-STn and observed by confocal microscopy. Blue-nuclei stained with DAPI, Green- tumor cells stained with anti-STn-Alexa 488, Redpolypeptide labeled with FNR 675. (Scale bar $20 \mu \mathrm{m}$ ). 
Flow Cytometric Analysis. A total of $2 \times 10^{5}$ HEK293 (Human Embryonic Kidney), HT-29 (Human Colorectal Adenocarcinoma) and 5637 (Human Bladder Carcinoma) cells were incubated with $10 \mu \mathrm{M}$ Alexa 488-labeled Bld-1 peptide, $\mathrm{ELP}_{77}$, and $\mathrm{B}_{5} \mathrm{~V}_{60}$ protein for $1 \mathrm{~h}$ at $4{ }^{\circ} \mathrm{C}$. Cells were washed twice with PBS and suspended in $200 \mu \mathrm{l}$ of PBS then subjected to flow cytometric analysis (BD Bioscience, San Jose, CA, USA). For analysis 20,000 cells were counted for each sample.

Confocal Microscopy. To test binding specificity, 5637, HT-29, and HEK293 cells were seeded on a four-chambered slide $\left(8 \times 10^{4} /\right.$ well $)$ and grown to $80 \%$ confluence. After $24 \mathrm{~h}$, cells were incubated with $10 \mu \mathrm{M}$ Alexa 488 -labeled $\mathrm{ELP}_{77}$ and $\mathrm{B}_{5} \mathrm{~V}_{60}$ for $1 \mathrm{~h}$ at $4{ }^{\circ} \mathrm{C}$ or for $30 \mathrm{~min}$ at $37^{\circ} \mathrm{C}$. Cells were then fixed with $4 \%$ paraformaldehyde (Sigma Aldrich) and cell membrane marker, Wheat germ agglutinin (WGA) Alexa Fluor 594 conjugate (Molecular Probes, Inc., Eugene), and cell nuclei were stained with DAPI (Sigma Aldrich). Images were captured by a Zeiss LSM-510 Meta confocal microscope.

STn Expression analysis. 5637 and HT-29 $\left(1 \times 10^{6}\right)$ cells were incubated with anti-Sialyl Tn antibody (Abcam, Seoul, South-Korea) and IgG isotype antibody as a control for $1 \mathrm{~h}$ at room temperature. Cells were further washed with PBS to remove excess or unbound antibody and subjected to flow cytometry to measure the level of STn receptor expression. A total of 20,000 events were collected for each sample.

Competition Assay. A total of $1 \times 10^{6} 5637$ cells were collected and pretreated with anti-Sialyl Tn antibody at different concentrations ( 5 and $10 \mu \mathrm{g}$ ) at room temperature for $1 \mathrm{~h}$. Cells were washed and incubated with $10 \mu \mathrm{M}$ Alexa 488 -labeled proteins for $1 \mathrm{~h}$ at $4{ }^{\circ} \mathrm{C}$. After several washes with PBS, cells were suspended with $200 \mu \mathrm{l}$ of PBS and subjected to flow cytometry.

Co-localization Assay. A total of $8 \times 10^{4} 5637$ and HT-29 cells were seeded on a four-chambered slide. After $24 \mathrm{~h}$, cells were incubated for $1 \mathrm{~h}$ with anti-Sialyl Tn (1:100) antibody labeled with FITC at room temperature. Cells were further incubated with $10 \mu \mathrm{M}$ FNR 675 -labeled E77 and $\mathrm{B}_{5} \mathrm{~V}_{60}$ for $1 \mathrm{~h}$ at $4{ }^{\circ} \mathrm{C}$. After several washes with PBS, cell nuclei were stained with DAPI (Sigma Aldrich) for $3 \mathrm{~min}$. Images were captured by a Zeiss LSM-510 Meta confocal microscope.

In vivo Fluorescence Imaging. All animal experiments were reviewed and approved by the Committee on the Ethics of Animal Experiments of the Kyungpook National University (Permit Number KNU 2016-0083). This study strictly followed the recommendations of National Institute of Health (NIH) for the Care and Use of Laboratory Animals. Athymic nude mice (BALB/c nu/nu) were housed in a specific pathogen-free environment at $22 \pm 2{ }^{\circ} \mathrm{C}, 55 \pm 5 \%$ relative humidity with light. Tumors were created by subcutaneously injecting 5637 cells $\left(5 \times 10^{6}\right.$ cells) into the right flanks of 5 week-old female mice. Tumors size (3-5 $\mathrm{mm}$ in diameter) usually develop within 1 month. Actually, the tumor sizing around $5 \mathrm{~mm}$ in diameter is more effective for our peptide delivery studies rather than tumor size below $3 \mathrm{~mm}$ in diameter. Mice bearing a subcutaneous tumor were anesthetized with $1.5 \%$ isoflurane inhalation and injected intravenously with approximately $3 \mathrm{mg} / \mathrm{kg}$ of FNR675-labeled ELP $(\mathrm{n}=10)$ and $\mathrm{B}_{5} \mathrm{~V}_{60}(\mathrm{n}=10)$. In vivo fluorescence images were taken at different time points after anesthetization ( $0 \mathrm{~min}, 1 \mathrm{~h}, 2 \mathrm{~h}, 4 \mathrm{~h}, 6 \mathrm{~h}, 12 \mathrm{~h}$, and $24 \mathrm{~h}$ ) using Optix eXplore (ART, Advanced research technologies Inc., Montreal, Canada).

Ex vivo Fluorescence Imaging and Tissue Preparation. Twenty-four hours after intravenous injection, animals were euthanized with $\mathrm{CO}_{2}$, and tumor and organs were collected. Ex vivo fluorescence images were then taken. Tumor tissues were fixed with $4 \%$ paraformaldehyde overnight and frozen for cryosectioning. Tissues were sectioned with $8 \mathrm{~mm}$ thickness and incubated with anti-STn antibody (1:100) overnight. Tissues were stained with Alexa 488-labeled goat anti-mouse IgG secondary antibody (1:200), whereas nuclei were stained with DAPI and observed under a confocal microscope.

Statistical Analysis. Statistical significance of differences between experimental and control groups was analyzed by Student's t-test for two groups or one-way analysis of variance (ANOVA) for more groups. $\mathrm{P}<0.05$ was set as statistical significance, was denoted by asterisks in the figures.

\section{References}

1. Jain, R. K. The next frontier of molecular medicine: delivery of therapeutic. Nat. Med. 4, 655-657 (1998).

2. Peer, D. et al. Nanocarriers as an emerging platform for cancer therapy. Nat. Nanotechnol. 2, 751-760 (2007).

3. Yu, B., Tai, H. C., Xue, W., Lee, L. J. \& Lee, R. J. Receptor- targeted nanocarriers for therapeutic delivery to cancer. Mol. Membr. Biol. 27, 286-298 (2010).

4. Vartak, D. G. \& Gemeinhart, R. A. Matrix metalloproteases: underutilized targets for drug delivery. J. Drug Target. 15, 1-20 (2007).

5. MacEwan, S. R., Callahan, D. J. \& Chilkoti, A. Stimulus-responsive macromolecules and nanoparticles for cancer drug delivery. Nanomedicine 5, 793-806 (2010).

6. Lee, E. S., Gao, Z. \& Bae, Y. H. Recent progress in tumor pH targeting nanotechnology. J. Controlled Release 132, 164-170 (2008).

7. Manchun, S., Dass, C. R. \& Sriamornsak, P. Targeted therapy for cancer using pH-responsive nanocarrier systems. Life Sci. 90, 381-387 (2012)

8. Kizaka-Kondoh, S., Inoue, M., Harada, H. \& Hiraoka, M. Tumor hypoxia: A target for selective cancer therapy. Cancer Sci. 94, 1021-1028 (2003).

9. Wilson, W. R. \& Hay, M. P. Nat. Rev. Cancer. 11, 393-410 (2011).

10. Hanahan, D. \& Weinberg, R. A. The hallmarks of cancer. Cell. 100, 57-70 (2000).

11. Giancotti, F. G. \& Ruoslahti, E. Integrin signaling. Science. 285, 1028-1032 (1999).

12. Simnick, A. J., Valencia, C. A., Liu, R. \& Chilkoti, A. Morphing low affinity ligands into high avidity nanoparticles by thermally triggered self-assembly of a genetically encoded polymer. ACS Nano. 4, 2217-2227 (2010).

13. Ruoslahti, E., Bhatia, S. N. \& Sailor, M. J. Targeting of drugs and nanoparticles to numors. J. Cell Biol. 188, 759-768 (2010). 
14. Mammen, M., Choi, S. K. \& Whitesides, G. M. Polyvalent interactions in biological systems: Implications for design and use of multivalent ligands and inhibitors. Angew. Chem. Int. Ed. 37, 2755-2794 (1998).

15. Accardo, A., Tesauro, D. \& Morelli, G. Peptide-based targeting strategies for simultaneous imaging and therapy with nanovectors. Polymer Journal. 45, 481-493 (2003).

16. Pasqualini, R. \& Ruoslahti, E. Organ targeting in vivo using phage display peptide libraries. Nature. 380, 364-366 (1996).

17. Ellerby, H. M., Arap, W. \& Ellerby, L. M. Anti-cancer activity of targeted proapoptotic peptides. Nat Med. 5, 1032-1038 (1999).

18. Joyce, J. A., Laakkonen, P. \& Bernasconi, M. Stage-specific vascular markers revealed by phage display in a mouse model of pancreatic islet tumorigenesis. Cancer Cell. 4, 393-403 (2003).

19. Koivunen, E., Arap, W. \& Valtanen, H. Tumor targeting with a selective gelatinase inhibitor. Nat. Biotechnol. 17, 768-774 (1999).

20. Pasqualini, R., Koivunen, E. \& Ruoslahti, E. Alpha v Integrins as receptors for tumor targeting by circulating ligands. Nat. Biotechnol. 15, 542-546 (1997).

21. Arap, W., Pasqualini, R. \& Ruoslahti, E. Cancer treatment by targeted drug delivery to tumor vasculature in a mouse model. Science. 279, 377-380 (1998).

22. Lee, S. M., Lee, E. J. \& Hong, H. Y. Targeting bladder tumor cells in vivo and in the urine with a peptide identified by phage display. Mol. Cancer Res. 5, 11-19 (2007).

23. Jia, X. Y., Yu, Q., Zhang, Z. H. \& Yang, X. F. Targeting bladder tumor cells in voided urine of chinese patients with FITCCSNRDARRC peptide ligand. Onco. Targets and Therapy. 5, 85-9 (2012).

24. Wang, P. H. et al. Altered mRNA Expressions of Sialyltransferases in Ovarian Cancers. Gynecol. Oncol. 99, 631-639 (2005).

25. Videira, P. A. et al. ST3Gal.I sialyltransferase relevance in bladder cancer tissues and cell lines. BMC Cancer. https://doi. org/10.1186/1471-2407-9-357 (2009).

26. Schneider, F. Overexpression of sialyltransferase CMP-sialic Acid: Galbetal, 3GalNAc-R alpha6-Sialyltransferase is related to poor patient survival in human colorectal carcinomas. Cancer Res. 61, 4605-4611 (2001).

27. Meyer, D. E. \& Chilkoti, A. Quantification of the effects of chain Length andconcentration on the thermal behavior of elastin-like polypeptides. Biomacromolecules. 5, 846-851 (2004).

28. Shamji, M. F. et al. Development and characterization of a fusion protein between thermally responsive elastin -like polypeptide and interleukin-1 receptor antagonist sustained release of a local anti-inflammatory therapeutic. Arthritis \& Rheumatism. 56, 3650-3661 (2007).

29. Wu, Y., Mackay, J. A., Mc Daniel, J. R., Chilkoti, A. \& Clark, R. L. Fabrication of elastin-like polypeptide nanoparticles for drug delivery by electrospraying. Biomacromolecules. 10, 19-24 (2009).

30. Massodi, I., Bidwell, G. L. III \& Raucher, D. Evaluation of cell Penetrating peptides fused to elastin-like polypeptide for drug delivery. J. Control. Release. 108, 396-408 (2005).

31. MacEwan, S. R. \& Chilkoti, A. Controlled apoptosis by thermally toggled nanoscale amplifier of cellular uptake. Nano Letters. 14, 2058-2064 (2014).

32. Sarangthem, V. et al. Construction and application of elastin like polypeptide containing IL-4 receptor targeting peptide. Plos one. 8(12), e81891 (2013).

33. Meyer, D. E., Kong, G. A., Dewhirst, M. W., Zalutsky, M. R. \& Chilkoti, A. Targeting a genetically engineered elastin -like polypeptide to solid tumors by local hyperthermia. Cancer Res. 61, 1548-1554 (2001).

34. Yuan, F. et al. Vascular permeability in a human tumor xenograft: molecular size dependence and cut-off size. Cancer Res. 55, 3752-3756 (1995).

35. Ryu, J. S. \& Raucher, D. The Influence of its molecular weight on local hyperthermia-induced tumor accumulation. Eur. J. Pharm. Biopharm. 88, 382-389 (2014).

\section{Acknowledgements}

These work is supported by the National Research Foundation of Korea (NRF) grant funded by the Korea Government (2014R1A5A2009242). This research was also supported by a grant of the Korea Health Technology R\&D Project through the Korea Health Industry Development Institute (KHIDI), funded by the Ministry of Health \& Welfare, Republic of Korea (HT15C0003). The authors are grateful to Kang Ji Eun and Thoudam Debraj Singh for technical assistance.

\section{Author Contributions}

Vijaya Sarangthem and Eun A. Cho equally contributed to this work and perform all the experiments, while Aena Yi,Sang Kyoon Kim and Byung-Heon Lee help in revising the manuscript. Design of experiments, concept and wrote the manuscript by Vijaya Sarangthem and Rang-Woon Park.

\section{Additional Information}

Supplementary information accompanies this paper at https://doi.org/10.1038/s41598-018-21910-z.

Competing Interests: The authors declare no competing interests.

Publisher's note: Springer Nature remains neutral with regard to jurisdictional claims in published maps and institutional affiliations.

Open Access This article is licensed under a Creative Commons Attribution 4.0 International

License, which permits use, sharing, adaptation, distribution and reproduction in any medium or format, as long as you give appropriate credit to the original author(s) and the source, provide a link to the Creative Commons license, and indicate if changes were made. The images or other third party material in this article are included in the article's Creative Commons license, unless indicated otherwise in a credit line to the material. If material is not included in the article's Creative Commons license and your intended use is not permitted by statutory regulation or exceeds the permitted use, you will need to obtain permission directly from the copyright holder. To view a copy of this license, visit http://creativecommons.org/licenses/by/4.0/.

(c) The Author(s) 2018 